\title{
Deliberative Democracy, Active Citizenship and Critical Culture: From Aristotle's Rhetoric to Contemporary Political Philosophy
}

\section{Democracia deliberativa, ciudadanía activa y cultura crítica: De la Retórica de Aristóteles a la filosofía política contemporánea}

Francisco Arenas Dolz

Profesor Contratado Doctor, Facultat de Filosofia i Ciències de l'Educació, Universitat de València

Fecha de recepción: 8 de octubre de 2012 Fecha de revisión: 9 de noviembre de 2012 Para citar este artículo: Arenas Dolz, F. (2013): Deliberative Democracy, Active Citizenship and Critical Culture: From Aristotle's Rhetoric to Contemporary Political Philosophy, Icono 14, volumen 11 (1), pp. 163-193. doi: $10.7195 /$ ri14.v11i1.518 


\section{Resumen}

Este trabajo tiene como objetivo defender una lectura adecuada de la retórica aristotélica que nos permita comprender la racionalidad práctica como un proceso de interpretación de las acciones humanas. A partir de la consideración de la retórica como una facultad humana general indispensable para la convivencia politica, se insiste en el impacto de la propuesta retórica aristotélica no sólo como una defensa de la importancia de la retórica en una sociedad democrática, sino también como un intento novedoso por comprender qué significa hablar de racionalidad práctica.

\section{Palabras clave}

Democracia - educación moral - ética - filosofía política - participación ciudadana pensamiento crítico

\section{Abstract}

The aim of this paper is to defend an adequate reading of Aristotle's deliberative rhetoric that allows us to understand practical rationalization as a process of interpretation of human actions. After the consideration of rhetoric as a general human ability that is indispensable for political coexistence, the impact of the Aristotelian rhetorical proposal is presented, not just as a defense of the importance of rhetoric in a democratic society, but also as a novel attempt to understand what it means to speak of practical rationality.

\section{Key Words}

Citizen participation - critical thinking - democracy - ethics - moral education political philosophy 


\section{Introduction}

This work starts from the thesis that rhetoric, in its Aristotelian sense, is most properly understood as an authentic theory of knowledge, not as an art form restricted to specific linguistic situations. It follows that analogy functions not merely as a rhetorical strategy, but as the only way in which human beings can know and express themselves. Analogy is not simply an ornament to be used in concrete situations, but a crucial mechanism in all modes of linguistic expression, a process of incarnation through which meaning turns to word.

Politics needs idealising analogies. Given the contingency of human affairs, we will always be in need of new clarifying analogies. Constructing them is one of the tasks appropriate to political theory or philosophy, according to Aristotle. Analogies are necessary in order to make sense of complex hard-to-see phenomena like politics, especially the current deliberative model of democracy. The problem to which deliberative democracy is a solution is this: "Find a model or an analogical metaphor to clarify our sense of what democratic politics is and should be. In crafting this idealising model or metaphor, you must stress liberty and equality, and you must not rely on any particular tradition or revealed religion." The deliberative model's answer to this question is that democracy is like a shared discussion among friends about matters of mutual concern calling for action. It stands as a rival to other solutions to the same problem: the liberal metaphor that ideal democracy is like a contract among individuals; the metaphor of participatory democracy, that ideal democracy is like a progressive revolutionary movement; the metaphor of communitarianism, that ideal democracy is like a family or band.

This essay sets out to develop three main theses:

1. The current model of deliberative democracy in its Rawlsean and Habermasean versions is not necessarily incompatible with the Aristotelian theory of deliberation.

2. The Aristotelian deliberative rhetoric model provides us with more plausible foundations than any other model for establishing a deliberative paradigm of democracy. On these bases I shall defend an interpretation of Aristotelian rhetoric understood as a faculty that is indispensable for the exercise of citizenship.

3. Rhetoric, as theorised by Aristotle, not only studies the natural human way of reasoning from which emerges a "technique of thinking" that makes us aware

DOI: ri14.v11i1.518 | ISSN: 1697-8293 | Año 2013 Volumen 11 Nº1 | ICONO14 
and critical of the usage of words, but furthermore, it provides us with a conceptual apparatus and the discursive rules for deliberating and communicating opinions, with the aim of grading the alternative possibilities with regard to that which is convenient and acceptable, and thus choosing a possible alternative and making the decision to follow it through as well as finding the appropriate means for doing so. Rhetoric constitutes a basic element of human formation.

\section{Methods}

Deliberative democracy, a North American variation of the German theories of communicative action which has gained huge support especially in the academic field, currently represents a neo-Kantian alternative to the model of liberal democracy. This model has surpassed both participative democracy and communitarianism and is currently personified in Habermas' ethics of discourse as well as in Rawls and his followers. Both defenders of this Kantian-based deliberative model deny that their theory is another comprehensive or "metaphysical" theory, regardless of the fact that it contains conceptions of "public reason" and "moral freedom" which depend on such comprehensive views, and as a result of which both theorists exclude Aristotle from their approaches for considering him a defender of some sort of "essentialism".

For these reasons, I hope to avoid two common pitfalls in this exposition. In the first place, I am not trying to argue that Aristotle was a partisan avant la lettre of deliberative democracy. Nonetheless, and as I shall show, Aristotle provides us in his Rhetoric with an excellent framework that allows us to think about the question of deliberation (boúleusis) as a practice that belongs within the public sphere and which in many aspects goes further than the modern deliberative model (Bickford, 1996: 41-53). In the second place, neither shall I argue that an assessment of Aristotle demonstrates that the theory of deliberative democracy is useless. In fact, the deliberative model of democracy implies in many ways a clear improvement with regard to other current prominent models of democracy. The deliberative model provides us with an alternative for both the liberal "rights talk" and the communitarianists' exaggerations in their different modalities: MacIntyre's philosophy of virtue, originally Aristotelian and currently Thomist; Sandel's ontology of the

ICONO14 | Año 2013 Volumen 11 № 01 | ISSN: 1697-8293 | DOI: ri14.v11i1.518 
community; Taylor's anthropological hermeneutics; Nussbaum's attempt at founding an "Aristotelian social democracy"; Bellah's sociological attempts; Walzer's theory of justice, Rorty's "post-modern liberalism" and Etzioni's approaches (MacIntyre, 1981 and 1990; Sandel, 1998; Taylor, 1991; Nussbaum, 1990; Bellah, 1985; Walzer, 1983; Rorty, 1989; Etzioni, 1991 and 1996). Furthermore, a deliberative model of democracy allows us to question not only excessively spiritualised conceptions of "activism", "politics" or "citizenship" which have proved to be so expensive for the upholders of a model of participative democracy.

As I will argue, Aristotle discuses the question of deliberation using a style that cannot be taken to be a dogmatic or de-contextualised essentialism or a Rawlsean or Habermasean idealisation regarding what is considered to be better in democratic practices. The Aristotelian perspective represents a reasonable alternative to this dilemma by offering us, beyond alleged idealisations, a plausible theoretical framework that allows us not only to critically confront the most respectable beliefs and values (éndoxa) of any society, but also to re-think, in a manner that is more accurate than other modern theories, the role that character (ethos) and affects (páthos) play in deliberation.

\section{The deliberative model: John Rawls and Jürgen}

\section{Habermas}

During the last decades a new international order has emerged. This order is more global than ever before, and deliberation has become one of the normative bases of democratic theory. There is, however, in this context great ambiguity with regard to the meaning of the term "democracy". Thus, for instance, Rawls and Habermas disagree with regard to the concept of liberalism and its relation to democracy. Rawls speaks of his theory of justice in terms of "political liberalism", whereas Habermas holds a version of democratic theory that differs from the liberal and republican paradigms. Nonetheless, both share the idea that a good society must be a reasonable democracy where reason is understood in a non-instrumental sense. The emphasis on the centrality of reason is characteristic of the deliberative model and is what distinguishes it from the communitarianist 
and participative alternatives. A democracy should promote solidarity and the active search for the public good, but it will never situate this good on the top of its table of values, for this place corresponds to reason. Accordingly, the central question these authors will have to address will be to make explicit the concept of rationality that characterises the deliberative model. The Kantian base upon which the thinking of both authors sits shows us a clear shared commitment to a notion of freedom -which defines their respective models- and which is found in Kant's essay on the Enlightenment, where the emergence of "public reason" is described as the central element of the Enlightenment and where reason is defined not in cognitive terms but as obedience to the general laws that we give to ourselves as citizens. The Kantian Enlightenment represents the step from a guilty childhood -understood as the incapability of using one's own understanding without someone else's guidance- to maturity. When ascribing democracy to a modern project of enlightenment and autonomy understood in this way, the modern deliberative model gains philosophical strength.

According to this deliberative model, Rawls (1993) argues that a good democracy emerges from so-called "reasonable pluralism", and implies that, in an "ideal overlapping consensus" expressed through the principles of justice, every citizen embraces a comprehensive doctrine at the same time. Insofar as Rawls' doctrine of justice as fairness implies a "thin theory of the good", it also underlies its firm anti-perfectionist liberal commitment. In turn, this implies focusing on the primary social goods understood as "means for any end" rather than as goods in themselves (Rawls, 1971; 1995, 132-180). The changes in the way that the primary goods appear in Rawls' subsequent formulations do not alter their instrumental character; if in Theory of Justice the methodological implications employed in the design of the original position demand these goods in order to choose principles, in Political Liberalism these goods are justified by the substantive commitment of the theory to the conception of citizens as free and equal moral persons and as fully cooperating members of society. Thus, Rawls' later work, especially his confrontation with the communitarianists, has emphasised this non-perfectionist tendency, as opposed to a comprehensive moral conception (Martínez Navarro, 1992: 55-72).

For Habermas (1990), a good democracy would be one into which the "discursive formation of the will" integrates, through a process of reflexive debate, the core of a theory of democracy centred on discourse and in which the questions 
of moral-practical character can be resolved in a rational way. In Facticity and Validity (chapters 7 and 8 in particular) Habermas (1992) points out that the discussion ends with a programme on the ethical regulation of the negotiation processes, which means that these must become as close as possible to deliberation and results determined by the strength of the deliberants must be avoided. In his Theory of Communicative Action Habermas (1981) had already introduced the distinctions between System and Life-world [Lebenswelt]. In society there are two aspects which are intertwined but which are theoretically different: System and Life-world. The system is an objective reality that manifests itself in the external relations between the members of society. Nonetheless, in society we also find another reality, the Life-world, that is based upon mutual communication between the members of society. In the Life-world, the aim of all activity is reciprocal understanding. In this sense, the Life-world is a necessary pre-condition for all communicative interaction. System and Life-world thus make manifest two different types of rationality. The System is dominated by technical-instrumental rationality. In the Life-world communicative rationality takes place, this being a tool by means of which people can achieve a reciprocal understanding. The role of this type of rationality is argumentation and conviction; according to Habermas, in an ideal situation, and when following the norms of rational discourse, people can achieve a perfect reciprocal understanding. Therefore, the Habermasean idea of communicative rationality is based upon the theory of argumentation. However, system and life-world were not originally separated from each other. It is a fact that in modern societies the system continuously becomes detached from the life-world. According to Habermas, the system begins to colonise the life-world. The Habermasean analysis is highly important in order to understand how the processes of deliberation take place. In modern societies, the legitimacy of our deliberations is not only based upon formal validity but also upon the -rationallyaccepted or acceptable values in that society. Thus, the foundation of legitimacy is rooted in the life-world.

Therefore, and even though these two versions of deliberative democracy differ from each other with regard to the aims and the degree of institutionalisation, they both share the idea that the rational consensus achieved by means of debate should serve as normative guide for deliberative democratic politics. This has been argued, for instance, by Gutmann and Thompson (1997: 43 and 349-351),

DOI: ri14.v1 1i1.518 | ISSN: 1697-8293 | Año 2013 Volumen 11 Nº 01 | ICONO14 
who in Democracy and Disagreement suggest a distinction between negotiations conducted "in one's own interest" and those conducted "for the mutual good", the latter being the one that represents a truly deliberative process. In this work the authors indicate some of the criteria ("principles of accommodation") that must govern the attitude of the citizen during public deliberation. The "principles of accommodation" are three principles relative to the attitude embraced by citizens when deliberating with those with whom one disagrees. These principles provide us with the standards that guide our actions in those situations of disagreement and require an excellence of character, as well as a positive and constructive attitude towards those persons with whom we do not agree. This allows us to also define these principles as virtues. It is the very character of morally committed persons who, being open to the possibility of changing their minds or modifying their positions, distinguish between respectable and non-respectable opinions and self-reflect on their own commitments.

In the first place, Gutmann and Thompson cite mutual respect. This is the fundamental virtue upon which deliberation rests at the same time that it is linked to the ideal of reciprocity. It consists of: a) recognising, above all else, the other as equal with regard to dignity and respect; b) showing respect and a favourable attitude towards those persons with whom one disagrees; c) respecting others by means of honestly trying to understand and assess their suggestions and evaluations of their own suggestions; d) offering reasons that the others can understand; e) aiming to turn the best argument into the winning argument, without employing fallacies nor appealing to feelings, but rather aiming for the argument to be rational.

In the second place, they cite civic integrity. This principle is shown through the fact that: a) the deliberators are honest and sincere, and employ reasons in which they believe rather than doing so for strategic motives; b) an epistemic attitude must prevail according to which, during the deliberation, the deliberators must seek the best decision rather than trying to impose the decision that best suits their interests; $c$ ) people must behave in a coherent manner in relation to that which they defend.

In the third place we find civic magnanimity. This principle is reflected in relation to the arguments and reasons of those who disagree with us. It is itself based on two other principles. In the first place, the moral status of the other's

ICONO14 | Año 2013 Volumen 11 № 01 | ISSN: 1697-8293 | DOI: ri14.v11i1.518 
position must be recognised. The deliberators understand that the suggestions and positions of others reflect their sincere beliefs and do not attempt to find hidden strategic intentions in their words. On the other hand, this implies opening one's mind to the possibility of being convinced by the positions of others. This is the fundamental idea of deliberation. An open attitude must prevail which is capable of recognising the possibility that we might be in the wrong and accepting the adequacy of the theses of the other. For this reason, in deliberation, one must attend to the arguments rather than the person who formulates them, thus avoiding accusations of ad hominem.

Nevertheless, this deliberative model of democracy is founded on a paradox: By trusting rationality as the only criteria, it does not recognise the possibility of other different but plausible conceptions of rationality. This makes a more realistic description of deliberation necessary; that is to say, a description that incorporates the rational values of argumentation as well as other values, for convictions and beliefs, which have a considerable weight in the formation of political identities, are made manifest in the processes of deliberation. A deliberation which does not take into account personal interests and opinions is neither capable of arousing credibility and trust nor of motivating and engaging citizens. Conviction plays a very important role in any deliberation; it is for this reason that rhetorical persuasion is one of the main tools of deliberation. To take these tools seriously and to apply them to deliberation would lead us to full democracy. Full democracy is not what representatives, experts, great public institutions or voters do, but rather the exercise, the capacity or the power of seeing oneself as part of a group or of a wider circle; it is the acceptance of one's own responsibilities when being part of this whole and the will to act for a common good. Full democracy has to begin with the practice of a civil dialogue whereby one begins to listen and to learn about the "other", to see things through others' points of view and to recognise and broaden our own principles and values.

DOI: ri14.v11i1.518 | ISSN: 1697-8293 | Año 2013 Volumen 11 Nº1 | ICONO14 


\section{An alternative model of deliberation:}

\section{Republicanism}

Alongside Habermas' discursive ethics and Rawls' political liberalism, republicanism has also busied itself with the problem of deliberation. Republicanism differs from liberal representative democracy in the proposal of a model of deliberative democracy that integrates the normative as well as the empirical aspects of deliberation. The aim of republicanism is to find a way out from the political bi-polarisation between liberalism and communitarianism. Thus, republicanism aims to overcome both projects by means of the concept of freedom. Pettit's republicanism, for instance, accepts freedom as the benchmark and, by means of the concept of non-domination, aims for freedom to be effective between individuals. Nonetheless, the struggle against the vulnerability caused by the problem of domination grants the law and the State a fundamental role, the State in particular acquiring a centrality that liberal ideology denies it. For this reason, and insofar as it is aware of the fact that participation produces a plural society, when submitting decisions for discussion republicanism attempts to promote the integration of different sensibilities, including respect for minorities.

Deliberation is part of the Republican ideal, by attempting to persuade each person to exhibit the (public) reasons for their points of view and by minimising the risks of politics being converted into a business in the hands of interested parties. Deliberation brings to civil society that which usually, in political negotiation, takes place between political parties. Pettit approaches this concept by means of differentiating between negotiation and debate. The first is based on the agreement reached between groups of interest that is beneficial for them and does not demand from them too many concessions, while the concept of debate takes into consideration all the positions that the groups can recognise as relevant. Both forms are also differentiated by the fact that, when making decisions, these are restricted only to those who hold the power of negotiating, for decisions are made before negotiation (Pettit, 1999: 244-245). The interest by republicanism in deliberation is translated into the promotion of discussion and debate in such a way that the individual beliefs and values, as well as the horizons of experience, are revisable in the light of collective discussion and debate, at the same time that

ICONO14 | Año 2013 Volumen 11 № 01 | ISSN: 1697-8293 | DOI: ri14.v11i1.518 
alternative perspectives and additional information are also taken into account. The participation of active citizenship through social movements, and the debate that takes place when making decisions based upon deliberation, offer an alternative social movement that opposes a conception of the individual who is moved by his own interests and who is alien to the public sphere. Debate promotes a type of "delegated deliberation", alternative to a unitary model of deliberation, with different agents who perform different roles while deliberating and who, during this deliberation, express their points of view in a successive rather than simultaneous manner, as would be the case in a unitary model of deliberation (Goodin, 2005: 182-196; Richardson, 2002: 130-142).

In this sense, the study carried out by Lukensmeyer and Hasselblad-Torres (2006) is of special interest. According to them, there are good reasons to consider the centrality of public deliberation in a democratic society: 1) citizen participation in the formulation of policies and in making decisions can reduce conflict; 2) citizen participation can lead to better political decisions, which are more enduring and more intelligent; 3 ) engaging citizens when making decisions is something governments must do; 4) deliberation generates competence, capabilities and skills; 5) citizen participation makes manifest mutual understanding, generates links of trust between citizens and governmental institutions and can cause changes in political skills and behaviour. Based upon these reasons, Lukensmeyer and Hasselblad-Torres (2006: 21-23) indicate some criteria that should orient public deliberation: 1) it helps us clarify values; 2) it centres on action; 3 ) it avoids pre-determined results; 4) it profits from the exchange of information; 5) it facilitates discussion in small groups; 6) it involves relevant experts. As a result of this, according to Lukensmeyer and Hasselblad-Torres (2006: 7), the aims of public deliberation would be the following: 1) To inform: To provide citizens with objective and balanced information in order to help them understand the problem, the alternatives, the possibilities and/or solutions; 2) To consult: To obtain citizens' reactions regarding the analyses, alternatives and/or decisions; 3 ) To commit: To work directly with citizens during the process in order to ensure that their concerns and aspirations are continuously being understood and taken into consideration; 4) To collaborate: To collaborate with citizens in all aspects of the decision, including the development of alternatives and the identification of solutions; 5) To empower: To place the authority in the hands of citizens for them to make the 
final decision. The authors distinguish between "citizen engagement" and "citizen participation". "Citizen participation", much "weaker" than "citizen engagement", promotes only the first two aims, i.e., to inform and to consult, from a conception based upon the formal techniques of participation that leave aside the values and convictions of citizens. "Citizen engagement" goes further insofar as it maximises the aims of citizen participation and promotes engagement, collaboration and empowerment from a more active conception of participation. Deliberative democracy plays a central role in the promotion of citizen engagement.

In many instances of his work, Aristotle insists on the importance of deliberation and offers us an architectural framework for the exercise of practical reasoning on the basis of a deliberative discourse (Salkever, 1991a; Richardson, 1997). Nevertheless, it is important to avoid two excesses. On the one hand, it is an exaggeration to label Aristotle as a pre-modern thinker or as a dogmatic essentialist. This is the caricature offered by those who, like Rawls (1993: 134-135) or Habermas (1992: 15 and 124) with their excessively historicistic approaches, are only able to see in Aristotle an anti-democratic and elitist thinker and, therefore, delimit the Aristotelian deliberative model within the borders of Greek society. On the other hand, however, the emphasis that Aristotle puts on the centrality of deliberation does not make him the father of deliberative democracy. This is the exaggeration that leads Nussbaum to defend, against Rawls, an "Aristotelian social democracy" and to formulate a founding frame, which she calls "internalist essentialism", that sits on a "vague and thick theory of the good" and which serves as an alternative to the Rawlsean version of justice. If the political aim is the production of combined capabilities rather than the real operation, then it is necessary to establish a set of minimums that allow citizens to choose and to determine the course of the operations as well as to use them and how to use them. It is with this in mind that Nussbaum attempts to apply the Aristotelian conception of distributive justice to a central aim: to try to define objective standards and norms of quality of life in order to measure and evaluate, from a normative concept of development, to what extent people can choose to develop those capabilities that correspond to a good life $^{2}$. Unlike these interpretations, I would like to suggest that the Aristotelian deliberative rhetorical model is based on critical principles which, being neither essentialist nor normative, are capable of promoting citizen engagement, collaboration and empowerment from which any deliberation is articulated.

ICONO14 | Año 2013 Volumen 11 № 01 | ISSN: 1697-8293 | DOI: ri14.v11i1.518 


\section{The Aristotelian approach}

Aristotle's Nicomachean Ethics and Politics do not constitute at all a reservoir of immutable truths. Instead, in these texts we find a general framework that can allow us to reflect on practical philosophy, insofar as this is a general framework based on reasonings that permit us to reach conclusions that can make information available for public discussion and that, in doing so by means of a nonessentialist or non-normative language, propels us towards a continuous reflection and a constant revision of our beliefs. I take thus the Aristotelian frame to be more plausible, more practical and more open than the one offered by many contemporary alternatives. This frame is teleological, implying that it is not merely factual, for it is not just a matter of explaining the particular phenomena according to adequate definitions; instead, it includes also the demand for understanding and relating these phenomena with the whole to which they belong (Gadamer, 1990: I 317-329; Apel, 1986: II 19-49). For all these reasons, it is possible to affirm that the hermeneutical framework offered by Aristotle is a critical framework: it is part of our inherent biological structure, however without this being understood in a deterministic fashion, but rather as a potential source from which to solve problems, configure capabilities and mould inclinations (Cortina, 1988: 166-193; 1996: 119-134; Conill, 2007).

In Nicomachean Ethics, Aristotle illustrates the nature of deliberation [Aristotle, $N E$ III 3, 1112a 18-1113a 14] $]^{3}$. In the first place, he indicates its object, namely the field of ethics and politics, and, more concretely, the actions taking place in this field that depend on us and that cannot be determined according to a science (episteme), and that belong instead to the sphere of that which in a certain way occurs in general (hos epi tò polý) [Aristotle, NE III 3, 1112a 21-31, 1112a 34-b 11]. It is for this reason that deliberation is different from scientific reasoning. Aristotle is building the foundations for the study of deliberation from an ethical, and not only technical, point of view. Deliberation is not something that is enacted abstractly; instead, it is always concretised in a particular choice. Unlike those authors who argue that the current means upon which we deliberate are universal (Belgum, 1990: 210), which leads them to reduce deliberation to a certain "practical syllogism", I suggest that it does not seem to be the case that deliberation addresses the universal. The Aristotelian efforts aim to demarcate the specificity of

DOI: ri14.v11i1.518 | ISSN: 1697-8293 | Año 2013 Volumen 11 Nº1 | ICONO14 
deliberative intelligence, which is oriented towards action, as opposed to speculative intelligence [Aristotle, NE VI 1, 1139a 10-11], thus highlighting the existence of a form of rationality of that which is contingent.

Human actions are intentional in the sense that they are voluntary (hekon), that is to say, it is the agent who has the power to act or not to act at the time of the action. As is the case of the human being, other animals are also capable of performing voluntary actions, given that the motivational power is neither the reason nor the will, but the desire (órexis), which is common to all animals [Aristotle, An. III 10, 433a 32-33]. The practical intellect presents to the soul, through the imagination (phantasia), an object of action that is subjectively considered to be a good. In order for this object to be turned into a principle of movement, intervention by the desiderative faculty is necessary, which converts the object represented into an end. Thus, Aristotle can argue, against Democritus, that all animals move by choice and intellection [Aristotle, An. I 3, 406b 24-25].

However, and in a greater measure than other animals, our desires are the result of learning and character (ethos) rather than of a biologically inherited reaction. Choice resides in a perception that responds flexibly to a concrete situation. The person of experience does not try to deal with a new situation by means of the intellect alone. Instead, the person makes use of desires shaped by deliberation, and of deliberation shaped by desires, and responds correctly with passion and with action. Choice is a capacity that sits on the border between the intellectual and the passionate and shares the nature of both: it can be characterised as desiderative deliberation or deliberative desire. In fact, Aristotle defines the human being as "desiderative thought" or "intellectual desire" [Aristotle, NE VI 2, 1139b 4-5]. Nevertheless, choice, which indicates not only the intention and purpose of an action but also the choice that necessarily leads to the action, is an operation of the practical intellect that makes the will effective, taking it to the performance of the action (prâxis), and includes desire, reasonable (boúlesis) or not, and a deliberation (boúleusis) on the means to achieve the end that the desire proposes [Aristotle, NE VI 2, 1139b 31-33]. Choice is "deliberated desire" [Aristotle, NE III 3, 1,113a 10]. Unlike those authors who understand the concept of proairesis as simply a kind of desire which is subsequent to deliberation (Allan, 1955: 334), choice expresses, on the one hand, the transmission of desire from the end towards the deliberative means, while, on the other hand, it also implies the desiderative ex- 
clusion of the other alternatives taken into consideration during the deliberation.

Therefore, that which distinguishes man's actions from animals' movements is not their intentionality. Aristotle reserves the term "action" (prâxis) for the human being. Even though animals have sensations [Aristotle, NE VI 1, 1139a 1018], and therefore have experience with pleasure and pain, and produce sounds as signs and sensations, they lack the human capacity to distinguish (krino) between good and evil, justice and injustice, as well as the capacity to communicate through words [Aristotle, Pol. I 2, 1253a 10-18]; only human beings have the capacity to think [Aristotle, An. II 3, 414b 18-19, 415a 7-9; III 3, 427b 6-14]. Of course, Aristotle is aware of the fact that animals' reactions are not fully passive. He recognizes the importance that sensory perception has in animals. Nonetheless, he insists on arguing that the critical capacity of the human logos is superior. It is for this reason that the behaviour of animals can never be considered to be an action (prâxis).

\section{Results}

\section{The social and rhetorical animal}

Without lógos, the development of human knowledge would be impossible. At the beginning of Politics, Aristotle establishes that man is the most social of all animals, due to the fact that it has lógos, understanding lógos as the capacity to deliberate about that which is good and evil, useful and useless, just and unjust, in order to make good choices [Aristotle, Pol. I 2, 1253a 7-19].

To say that man is a social animal implies saying that the structure of our lives is made of desires shaped by both thought and sensations. Nevertheless, Aristotle's text does not say that men are the only social animals, but rather that they are social animals in greater measure than other animals (Ramírez, 2003a: 220-223; 2003b: 3-4; Salkever, 1991b: 24-30; 1991c: 173-176). By arguing that man is the only ("political" or even "socio-political" depending on the translation) social animal (López Eire, 2005: 37), many interpreters fall into at least two erroneous ideas regarding the sense of Aristotle's argument. Having found in Aristotle a magnificent ally against the liberal individualism that they oppose, some authors have

DOI: ri14.v11i1.518 | ISSN: 1697-8293 | Año 2013 Volumen 11 Nº1 | ICONO14 
defended the superiority of political life over other modes of life (Arendt, 1958; Pocock, 1975: 550; Nussbaum, 1986: 345-353). This interpretation of politics as a good in itself clashes, however, with the comments at the end of Nicomachean Ethics and Politics, where Aristotle defends the superiority of the bios theorotikós over the bios politikós. In order to convert Aristotle into a biological determinist, other authors base their readings on the argument that affirms that «in all exists by nature an impulse (horme) toward such community» [Aristotle, Pol. I 2, 1253a 29-30], and thus they do not hesitate to maintain that Aristotle is saying that we have a natural impulse that we have inherited biologically and that leads us to live together. ${ }^{4}$ Nonetheless, for Aristotle, the aim of politics is not a life in community (syzen), but rather a good life (eû zen). The issue is not of biologically determined impulses, but rather of potential inclinations that are modifiable in accordance with experience [Aristotle, Pol. III 9, 1280b 39-1281a 4]. In summary, that man is a social animal is not the result of the superiority of political life over other modes of life, nor is it the consequence of a biologically necessary impulse. For Aristotle, politics is neither an end in itself nor something inevitable, but rather the most reasonable mode of organising the plurality of inclinations and needs that constitute our biological background; it is an activity that emerges as a result of our desire for a good life (eû zen). Human beings are the only animals with the capacity for feeling what is best for them and to order their lives accordingly. Only on the basis of these hypotheses is it possible to understand the breadth of Aristotle's text.

The sense of the term lógos in this passage is radically opposed to many current interpretations that convert Aristotle into a sort of defender of the theory of speech acts. For these exegetes, Aristotle would be maintaining that the purpose of lógos is to facilitate the exchange of information between people, thus reducing the meaning of the term to that of mere phoné (López Eire, 1995: 46). Nevertheless, lógos is that which allows us to discover, through deliberation, the means and ends with which we organise our lives. This capacity of lógos is a potentiality that may or may not develop, for human beings are capable of living well or badly.

The marked distinction between house (oikía) and city (pólis), maintained especially by those interpreters who defend the superiority of political life over other modes of life, is not seen in Aristotle, for both contribute to promoting a good life (eû zen) (Salkever, 1991c: 181). For Aristotle, the end of a home is

ICONO14 | Año 2013 Volumen 11 N 01 | ISSN: 1697-8293 | DOI: ri14.v1 1i1.518 
not simply procreation, for «in the house we find, above all, the principles and sources of friendship, of political organisation and of justice» [Aristotle, EE VII 10, 1242a 40-b 1]..$^{5}$ This highlights the importance of family where, through education (paideia), one acquires the sense of identity that allows one to deliberate (Nussbaum, 1980: 395-435; Saxonhouse, 1982: 202-219; Nagle, 2006). One of the objective principles of education is to prepare youths so that they can deliberate with regard to what is just and unjust, and can then become diligent (spoudaîoi) and autonomous citizens, that is, citizens capable of governing themselves and of governing the city (Miller, 2002: 375-402; Sherman, 1997: 325-330). The task of the citizens is thus to judge what differences are to be promoted and which ones are to be rejected for being harmful. Citizens try to find, through the exercise of deliberation, mutual agreement among themselves that expresses their thought and feelings, communicating it to one another in order to be able to develop their life in community. This way, the differences promote dialogue, social progress and criticism within the framework of the pólis (Salkever, 1991a: 166-167).

\section{The Aristotelian deliberative rhetorical model}

In order for the human being to be able to live well, act well, norms of action and criteria are needed [Aristotle, NE I 8, 1098b 21]. Rhetoric, which is the art of moving into action by means of lógos, consists of creating discourses capable of convincing with regard to which course of action is to be taken in each different case. In this way, rhetoric shows its intrinsic relationship with ethics. Rhetoric offers us the common places (tópika) that provide us with general ideas about concrete facts, principles of action that allow us to take rational decisions. These criteria do not move in the field of epistémé, but neither do they move in the field of mere empeiría. In fact, the development of a rhetoric that is completely detached from ethics and, also, from the principles that govern the creation of thoughts, is what will generate a bad rhetoric that is only concerned with the ornamentation of the discourse (Abizadeh, 2002: 267-296).

It must be noted that, in contradistinction to Plato [Phaedr. 270b; Gorg. 502e, 503a], Aristotle does not establish a distinction between good and bad rhetoric, but between sophistry and rhetoric. Aristotelian rhetoric is based on the discus- 
sion of plausible opinions (éndoxa), generally accepted opinions, consisting of that «which is acceptable to all, or to the majority, or to the wise, and among the latter, to all, to the majority or to the best known and most reputable» [Aristotle, Top. I 1, 100b 21]. The plausible opinions (éndoxa), which manifest the trust of human reason in the opinions of others, emerge from experience and acquire the register of clichés and the common use of language. One of the aims of Aristotle's Rhetoric is to counter Plato's low appreciation of this discipline. Aristotle rescues the value of rhetoric from Plato, who associated it with the adulation with which the Sophists tended to act in his time. Aristotle begins by arguing that the faculty of speech «is more specific to the human being than the use of the body», and considers it to be one of the goods that the human being uses and the one thanks to which «one can be of great use when employing it with justice, and [can also] cause serious harm when used unjustly». The task of rhetoric «does not consist of persuading but rather of recognising the means of credibility (pisteis) that are most pertinent in each case in order to be convincing» [Aristotle, Rhet. I 2, 1355b 3-25]. A bad rhetoric does not take into consideration plausible opinions (éndoxa), but only apparent and paradoxical opinions, these being characteristic of a sophistic or eristic argumentation. If a good rhetoric is one used to clarify a good reasoning, bad rhetoric is one used to cast a shadow over a bad reasoning. If, from the Aristotelian perspective, rhetoric is related to the means of credibility (pisteis), a bad rhetoric is one that does not employ the means of credibility available. The good rhetoric is the one that, making use of rhetorical arguments, places all the means that are necessary for making a choice before the listener; that is to say, it is one which exercises the capacity for deliberation (boúleusis) previous to making any choice (proairesis) (Beuchot, 2007: 217-234).

For Aristotle, rhetoric has to do with «those matters upon which we deliberate and for which we do not have arts or systems to guide us, with this being in relation to the kind of listeners who cannot take in at a glance a complicated argument, or follow a long chain of reasoning. The subjects of our deliberation are such as they seem to present us with alternative possibilities: about things that could not have been, and cannot now or in the future be, other than they are, nobody who takes them to be of this nature wastes his time» [Aristotle, Rhet. I 2, 1357a 2-8]. In this definition I emphasis three aspects: 1) the necessity for deliberation regarding what appears to us as obvious, of easy resolution or of possible resolu-

ICONO14 | Año 2013 Volumen 11 № 01 | ISSN: 1697-8293 | DOI: ri14.v11i1.518 
tion in the field of other types of knowledge; 2) the limits of human nature on providing a solution to certain questions; 3 ) the probable character of that upon which one deliberates. One deliberates neither upon the impossible nor upon the natural or causal possible, but upon that on which our will depends and which can be different. Aristotle, aware of the fact that human knowledge is based more on well-founded opinions than on demonstrable truths, is of the view that the deductive rigour of the logical demonstration can hardly be applied to the resolution of everyday issues whereby one deliberates upon practical conflicts. This way, the integration of deliberation into the sphere of moral action implies abandoning definitively the criteria of scientificity as the only parameter of judgement.

From an Aristotelian perspective, a good rhetoric -an ethical rhetoric-is rhetoric 1) the aim of which is to provide means of credibility (pisteis) that are appropriate to any argument: lógos (the very coherence of the discourse), páthos (the affects the orator is capable of transmitting) and ethos (the orator's credibility and trust), thus allowing the orator to be in tune with the listener; 2) that deals with convincing, rather than with what is true, and therefore is based on enthymemes, that is to say, on deductive reasonings based on "likeliness and indications" which constitute "the body of conviction", neither for presenting half-truths nor for persuading, but rather because the premises of the argument can be neither true nor false but only probable; unlike science, which uses syllogisms formed by absolute premises that automatically lead to true conclusions; 3 ) that provides the listener with the criteria to be able to carry out an informed and just choice; 4) that pays attention to experiences and values in which our beliefs are rooted; 5) that is capable of avoiding the instrumentalisation of others, to the extent that it increases our knowledge of others; 6 ) that is the art of giving good reasons, being aware of the fact that in order to make reasons explicit one must know things, one must know the consequences of what is being said; 7) that, by dialogue, understands the joint search and the final finding of a truth, being aware of the fact that there is no dialogue unless there is predisposition, unless there is a reciprocal credit, emerging from the trust that the people engaged in the dialogue can mutually generate in each other, or emerging from an interest in the difference that each of the participants brings; 8) that is capable of guaranteeing assent, because any reasonable person should be convinced of what has been said; 9) that provides us with profitable thoughts and experiences for the -often unexpected- concrete si-

DOI: ri14.v11i1.518 | ISSN: 1697-8293 | Año 2013 Volumen 11 Nº1 | ICONO14 
tuations that we encounter. Such thoughts and experiences can perhaps resemble technical rules, although they are no more than mere advice or warnings. They are recommendations and indications of what must be taken into account or of that about which one must think in order to act in certain situations; 10) that requires that the orator exposes ideas in a clear manner, ordering their words appropriately. The discourse is brilliant when its expression springs forth with strength and spontaneity. All good rhetoric also includes knowledge of the listener to whom one is addressing the discourse. A good rhetoric also takes into account the receiver -the addressee of the discourse- he being the one who decides whether the received information can or cannot be validated. Thus, the character (ethos) of the orator is one of the key elements upon which good rhetoric is built. In order to assess the credibility transmitted by the orator, the listener considers the past and present words and actions of the orator. Without good rhetoric, education for the soul, moral education in general, is impossible. The educator must not only instil truths, but must also make them likeable. Faced with any pretension of axiological neutrality, good rhetoric is the art of being in tune rather than of manipulating; 11) that it is a good narration, credible (eikós), capable of shedding new light on reality, translating the possibilities of finding sense beyond that which is real. Good rhetoric is capable of inspiring the imagination (phantasia) through the narration of past stories (mythoi) that constitute the memory of the community. Thus, good rhetoric consists of the interpretation of lived experiences. Good rhetoric requires, therefore, imagination (phantasía) and awareness of the right time for acting (kairós); 12) that is aware of the fact that democracy is the condition that makes the birth and development of rhetoric possible. Good rhetoric defends every person's right to free speech so that not all opinions are equally respectable. If the current political oratory is not anymore like that of Aristotle's -that is to say an oratory for reflecting on actions to be performed or decisions to be made in the future- but is rather an oratory whose aim is to obtain a social and political consensus regarding previously made decisions as is the case in a representative democracy, then our possibilities for acting in defence of our rights require knowing how to use language and, as a result, being able to analyse discourse in order to discern what is implied, highlighted or hidden.

Discourse regarding that which is good and bad, useful and useless, just and unjust, constitutes the object of Aristotelian deliberative rhetoric [Aristotle, Rhet. 
I 4-8, 1359b 19-1366a 22]. Rhetoric allows human beings to reason with regard to their actions, coordinating them mutually and seeking common ends. In this sense, then, it is possible to suggest, from an Aristotelian perspective, that rhetoric is essential for the exercise of citizenship (Ramirez, 2003a: 235-237). Rhetoric has a clear political, social and citizenship-oriented dimension: the art of rhetoric must be useful to the citizen. This makes it possible to understand the importance of rhetoric, especially in a society concerned with defending the pólis, this being the task of all citizens. Rhetoric is thus understood here as a general human faculty that is indispensable for political coexistence.

The role of the orator is not to speculate regarding the ideal regime. Their task is to occupy themselves with the governments and the political and legislative application of each one of them, how this is usually understood and, above all, how it is to be applied. That is to say, what the orator takes into consideration is how each regime practices and not how they should practice. This makes manifest once again the political dimension of rhetoric. However, there is a reciprocal correspondence between the character of men and the regime that corresponds to them. In fact, they are mutually determining. Human beings manifest their character (ethos) in their moral choices and their tendencies toward a specific end [Aristotle, Rhet. I 8, 1366a 8-16]. The regime works in the same way. The orator must consider the character of his listeners in order to know how to instil trust in them. This means, however, that the orator must know both the character of the citizen and of the government [Aristotle, Rhet. I 8, 1366a 17-22]. This knowledge provides the orator with a much broader field of argument. What this means is that the orator can broaden the quantity of arguments, not only the deliberative ones but also the epidictic and judicial ones. This way -and contrary to current ethical intellectualisms and political utopianisms- rhetoric, from the centrality of character (ethos), provides reason with the possibility of opening itself to the concrete context of its actions. Many authors have currently defended such a "rehabilitation of ethos" (Bien, 1973; Ritter, 1969: 57-105 and 133-179). Without undermining the valuable contributions of these scholars, it must be said that this "rehabilitation of ethos", which implies considering the diverse genres of life, does not entail the consecration of the current ethos in the pólis, that is to say, of a life dedicated to political praxis; on the contrary, it aspires to the realisation of a way of life.

DOI: ri14.v11i1.518 | ISSN: 1697-8293 | Año 2013 Volumen 11 Nº1 | ICONO14 
In this sense, the relationship between political institutions and the education and development of the civic virtue and character of the citizens is inseparable. Civic virtue must be oriented towards the formation of people's character; they, as citizens, will recognise and feel their belongingness to a permanently nonexclusive community. From the Aristotelian point of view, the good human being and the good citizen go hand in hand. The characteristics that define virtuous men and good citizens cannot be sharply separated [Aristotle, Pol. III 4, 1277a 13-14]. The education of the spoudaîos does not only imply learning a set of téchnai; it also involves developing character virtues and promoting the capacity to choose well (Mara, 1998: 323). All these reflections show that a politics that takes rhetoric seriously is fundamental in order for educated citizens to be capable of judging correctly with regard to aspects of the city, if they deliberate together.

\section{Discussion}

The potential contained in the contributions made by the rhetorical tradition must be taken into consideration in the formation of citizens -for whom current education policies are being designed- given that the basic issue for a citizen of a modern society is the necessity for a critical command of language, for this is precisely what makes possible a critical comprehension and orientation of human action.

The concept of formation comes from classical culture and its concept of paideía, which means the formation of man as man, in its specificity of being-man, that is to say, linked to theorein, to production as poiesis and to his conscious participation in the life of the pólis. From Socrates to the Stoics, including Plato and Aristotle, but also from Isocrates to Plutarch, and later from Cicero to Quintilian, paideía became in Antiquity the elevated, reflective, authentically human pedagogical model oriented towards the educational formation of the aristoi (Marrou, 1971). The Greek paideía was followed by Christian paideia, humaniora from the Renaissance, 17th century pedagogical rationalism and the pedagogy of Bildung that elevates human formation to common potentiality for all human beings.

In the Greek world, the relationship between political institutions and education and the development of the civic virtue and character of citizens is insepara-

ICONO14 | Año 2013 Volumen 11 № 01 | ISSN: 1697-8293 | DOI: ri14.v11i1.518 
ble. The Greek paideía responds to the educational ideal of forming citizens. The Greek Project of paideía implies the formation of citizens capable of governing the pólis. The aim is not to transmit excessive theoretical knowledge to the youth, but to optimise their capabilities, to bring out the best in them, turning them into magnanimous citizens, that is to say, citizens capable of operating by themselves. Capable, that is, of being virtuous, excellent, and of living their lives in an authentically human manner, promoting their ability to choose well. The term paideía summarises the ideal of the Greek man. It not only refers to physical perfection, to the training of the body, but it also signifies a process of growth, of improvement: how to become an effective politician, an effective athlete, a good orator, a good philosopher, a good ruler, a good parent. The Greek paideía served thus to promote the development of the arts, the teaching of all branches of philosophy, the cultivation of aesthetics and gymnastics (Naval Durán, 1992). During the Hellenistic period, the Greek educative influences were transmitted through thinkers such as Plutarch, for whom the role of parents in the education of their children was a central point.

The Romans considered the teaching of rhetoric to be a fundamental aspect. For Quintilian, the adequate formation of an orator should develop from the study of language, literature, philosophy and the sciences, paying special attention to the development of character. Roman education transmitted the study of the Latin language, classical literature, engineering, law and governmental administration and organisation to the Western world. The grounds upon which the Monastic and Cathedralian schools of the first centuries of the Christian era were constituted were, precisely, the seven liberal arts, which were divided into the triuium (grammar, rhetoric and logic) and the quadriuium (arithmetic, geometry, astronomy and music), as we will find in Saint Isidore of Seville or in Casiodorus.

Humanism re-established all the disciplines that would contribute to a better knowledge and understanding of classical authors, who were considered to be the purest model of humanity on the basis of which to recreate the schools of GrecoLatin philosophical thought and to imitate the style and language of the classics, especially Cicero (Michel, 1960). During that period, grammar, rhetoric, literature, moral philosophy and history, -sciences closely linked to the human spirit- experienced an extraordinary development within the general framework of philosophy, Against the dogmatism of theology, exposed in systematic and abstract trea-

DOI: ri14.v11i1.518 | ISSN: 1697-8293 | Año 2013 Volumen 11 Nº1 | ICONO14 
ties which excluded the living word of dialogue, Humanism developed the liberal arts or all dignified types of knowledge of the free man. Humanism highlighted the centrality of the example, of conversation and coexistence. In this sense, an essential aspect of any humanist project would be teaching how to speak well: promoting the capacity to listen, stimulating pleasant conversation, cultivating the taste for beautiful things and true friendship. Among others, Thomas Moore and Erasmus of Rotterdam defended the idea of a truth without fanaticism. Both worked with the aim of rescuing Christian European culture from its decadence. However, neither of the two allowed himself to be swept away by extreme reactions that aimed to solve problems by destroying the existing order.

Rhetoric played an important role in the pedagogy of some of the most important humanists such as Pier Paolo Vergerio (1402, De ingenuis moribus et liberalibus), Leonardo Bruni (1422-1429, De studiis et litteris) and Eneas Silvio Piccolomini (1450, De liberorum educatione) (Vasoli, 1999: 45-129). The rediscovery in 1416 by Poggio Bracciolini of the works of Quintilian in Sankt-Gall, signals the origin of humanist pedagogy which owes its two most important contributions to Quintilian. On the one hand, the principle of the encyclopaedic formation of the individual, in which the technique of oratory no longer represents an end in itself as it did in the Middle Ages, and is instead oriented toward the development of the personality of the individual. For Quintilian, the orator must be vir bonus dicendi peritus. On the other hand, the taking into consideration of the specificity of childhood and the need for adapting pedagogy to particular cases.

The main features of humanist education could be summarised in three fundamental terms that we find in Policianus, the tutor of Lorenzo de Medici's children, in a letter addressed to the prince: Tu mihi tuos liberos in curam, in disciplinam, in tutelam tradidisti. "You have entrusted your children to my care, my teaching and my tutelage». Care-discipline-tutelage. In addition to all these technical aspects, pedagogy has a fundamentally psychogogical role in the humanist tradition, for it fundamentally implies the experience of seduction. The humanist continuously evokes models, resorts to analogies, invents examples. And through all these mythical examples, through these symbolic functions, the humanist makes manifest that which he considers to be constitutive of the main aim of education: to transmit the art of rhetoric, that is to say, to form, principally, a complete orator (Galand-Hallyn, 1999: 131-190; Margolin, 1999: 191-257).

ICONO14 | Año 2013 Volumen 11 № 01 | ISSN: 1697-8293 | DOI: ri14.v11i1.518 
In the twenty-first century, formation has become an «epochal category» that occupies the centre of social life. The society of different types of knowledge, of professions, demands a formation grounded in moral education (Rubio-Carracedo, 1996). Rhetoric constitutes an important «ground for praxis» that integrates the cognitive and affective aspects of action (Beuchot, 1998: 117). This «rhetorical» way signifies, in summary, an important ground for the construction of contemporary ethics (López de la Vieja, 2003). The hermeneutical philosophy of education, rooted in the exercise of narrative, finds in the rhetorical dynamism of truth in-process a mediating concept «that enriches all the structural and content framework of the educational experience» (Esteban Ortega, 2002: 122). Hermeneutics, which advocates the historical-narrative and practical character of truth, finds in rhetoric an important ground for the actualization of formation, for «the truthful has neither a metaphysical nor logical nature, but a rhetorical one» (Vattimo, 1983: 38).

I am suggesting that the democratic exercise of modern societies demands the return of rhetoric and argumentation not only to the world of civil, judicial and economic affairs, but, primordially, to the educational sphere. The homo sapiens is not only a homo loquens, but also a homo rhetoricus. The human being finds in communication an indicator of sense. Insofar as they are aware of this fact, current reflections have situated communication at the centre of their research. Many thinkers have assigned a fundamental role to communication, recognising it in language, in ethics, in argumentation, in narrative, and identifying the communicative act as the one that constitutes the very rationality of homo sapiens and of their very cultural history (Ramírez, 2001: 115-145).

There are two pillars that sustain this idea of rhetorical formation: an active citizenship and a critical culture. Democracy needs a "democratic" state, but it also needs informed, vigilant and active citizens, as well as institutions and associations that act as guardians of the transparency of the state, especially through the institutions that regulate public opinion. Democracy is, and is founded on, communication. The articulation of communication is a key element, the decisive aspect of democracy. It is on this basis that we can speak of the necessity of having to constantly re-think democracy and of always projecting it from an ideal framework that allows it to act as a regulative principle, from which it can then carry out a constant critique of the real models of democracy. Furthermore,

DOI: ri14.v11i1.518 | ISSN: 1697-8293 | Año 2013 Volumen 11 Nº1 | ICONO14 
to educate and form authentic citizens -homines boni dicendi periti, according to the Catonian definition of the orator- does not mean the formation of specialists on one single subject-matter, but rather signals the advancement of a model of education that is capable of joining prudence and wisdom and that finds in the humanist tradition -and particularly, in rhetoric- one of its best allies.

\section{Notes}

[1] This study is part of the Projects of Scientific Research and Technological Development FFI201021639-C02-01, "Ética del discurso, política democrática y neuroética" and FFI2012-35734, "Retórica y ficción narrativa de la Ilustración a los romanticismos (en las literaturas española, francesa, inglesa y alemana)", funded by the Ministry of Economy and Competitiveness (Spain) as well as by the European Regional Development Fund FEDER from the European Union.

[2] Nussbaum's position differs notably from Sen's, for whom the proposal to ensure a real freedom by means of centering the attention in the capabilities, rather than in the possession of assets, is compatible with a political conception of justice like that one of Rawls (Crocker, 1992: 584612; Conill, 2004: 175-198).

[3] In this essay I cite the works of Aristotle according to the 0xford Classical Texts editions.

[4] For a severe critique of this position see Gotthelf, 1976: 226-254; Nussbaum, 1978: 59-106; Balme, 1980: 1-12.

[5] In this context, Aristotle underlines also the analogy between oikía and pólis, which he then takes as forms of coexistence that differentiate human beings from other animals (Aristotle, EE VII 10, 1242a 22-27).

\section{References}

Abizadeh, A. (2002). The Passions of the Wise: Phronêsis, Rhetoric, and Aristotle's Passionate Practical Deliberation. The Review of Metaphysics, 56, 267-296.

Allan, D.J. (1955). The Practical Syllogism. En L. De Raeymaeker, G. Verbeke, M. De Corte et alii (Eds.), Autour d'Aristote. Recueil d'études de philosophie ancienne et médievale offert à Monseigneur A. Mansion (pp. 325-340). Louvain: Publications Universitaires de Louvain. 
Apel, K.O. (1986). The Erklären-Verstehen controversy in the philosophy of the natural and human sciences). En G. Fløistad (Ed.), Contemporary philosophy: A new survey (vol. 2, pp. 19-49). Dordrecht: Martinus Nijhoff Publishers. Arendt, H. (1958). The Human Condition. Chicago: The University of Chicago Press.

Balme, D.W. (1980). Aristotle's Biology Was Not Essentialist. Archiv für Geschichte der Philosophie, 62, 1-12.

Belgum, E. (1990). Knowing Better: An Account of Akrasia. New York: Garland Press.

Bellah, R.N. (1985). Habits of the Heart: Individualism and Commitment in American Life. Berkeley: University of California Press.

Beuchot, M. (1998). La retórica como pragmática y hermenéutica. Barcelona: Anthropos.

Beuchot, M. (2007). Retórica y hermenéutica en Aristóteles. Noua Tellus. Anuario del Centro de Estudios Clásicos, 25(1), 217-234

Bickford, S. (1996). The Dissonance of Democracy: Listening, Conflict, and Citizenship. Ithaca: Cornell University Press.

Bien, G. (1973). Die Grundlegung der politischen Philosophie bei Aristoteles. Friburg-München: Alber.

Conill, J. (2004). Horizontes de economía ética. Aristóteles, Adam Smith, Amartya Sen. Madrid: Tecnos.

Conill, J. (2007). Ética hermenéutica. Crítica desde la facticidad. Madrid: Tecnos. Cortina, A. (1988). La reconstrucción de la racionalidad práctica. Más allá del procedimentalismo y el sustancialismo. Estudios Filosóficos, 104, 166-193 Cortina, A. (1996). El estatuto de la ética aplicada. Hermenéutica crítica de las actividades humanas. Isegoría, 13, 119-134

Crocker, D.A. (1992). Functioning and Capability. The Foundations of Sen's and Nussbaum's Development Ethics. Political Theory, 20(4), 584-612

Esteban Ortega, J. (2002). Memoria, hermenéutica y educación. Madrid: Biblioteca Nueva.

Etzioni, A. (1991). A Responsive Society: Collected Essays on Guiding Deliberate Social Change. San Francisco: Jossey-Bass Publishers.

Etzioni, A. (1996). The New Golden Rule: Community and Morality in a Democratic Society. New York: BasicBooks.

DOI: ri14.v11i1.518 | ISSN: 1697-8293 | Año 2013 Volumen 11 Nº1 | ICONO14 
Gadamer, H.G. (1980). Wahrheit und Methode. Grundzüge einer philosophischen Hermeneutik, en Gesammelte Werke. Tübingen: Mohr.

Galand-Hallyn, P. (1999). La rhétorique en Italie à la fin du Quattrocento (14751500). En M. Fumaroli (Ed.), Histoire de la rhétorique dans l'Europe moderne. 1450-1950 (pp. 131-190). Paris: PUF.

Goodin, R.E. (2005). Sequencing Deliberative Moments. Acta Politica, 40, 182196. doi:10.1057/palgrave.ap.5500098

Gotthelf, A. (1976). Aristotle's Conception of Final Causality. Review of Metaphysics, 30, 226-254

Gutmann, A. \& Thompson, D. (1997). Democracy and Disagreement. Cambridge: Harvard University Press.

Habermas, J. (1981). Theorie des kommunikativen Handelns. Frankfurt am Main: Suhrkamp.

Habermas, J. (1990). Moral Consciousness and Communicative Action. Cambridge: Polity Press.

Habermas, J. (1992). Faktizität und Geltung. Beiträge zur Diskurstheorie des

Rechts und des demokratischen Rechtsstaats. Frankfurt am Main: Suhrkamp.

López de la Vieja, Ma T. (2003). Ética y literatura. Madrid: Tecnos.

López Eire, A. (1995). Actualidad de la Retórica. Salamanca: Ediciones

Universidad de Salamanca.

López Eire, A. (2005). La naturaleza retórica del lenguaje. Logo. Revista de

Retórica y Teoría de la Comunicación, 5(8-9).

Lukensmeyer, C.J. \& Hasselblad-Torres, L. (2006). Public Deliberation: A Manager's

Guide to Citizen Engagement. Washington D.C.: IBM Center for The Business of Government.

MacIntyre, A. (1981). After Virtue: A Study in Moral Theory. London: Duckworth. MacIntyre, A. (1990). Three Rival Versions of Moral Enquiry: Encyclopaedia, Genealogy and Tradition. Notre Dame: University of Notre Dame Press. Mara, G.M. (1998). Interrogating the Identities of Excellence: Liberal Education and Democratic Culture in Aristotle's Nicomachean Ethics. Polity, 31(2), 301329.

Margolin, J.C. (1999). L'apogée de la rhétorique humaniste (1500-1536). En M. Fumaroli (Ed.), Histoire de la rhétorique dans l'Europe moderne. 1450-1950 (pp. 191-257). Paris: PUF.

ICONO14 | Año 2013 Volumen 11 № 01 | ISSN: 1697-8293 | DOI: ri14.v11i1.518 
Marrou, H.I. (1971). Histoire de l'éducation dans l'antiquité. Paris: Editions du Seuil.

Martínez Navarro, E. (1992). La polémica de Rawls con los comunitaristas.

Sistema, 107, 55-72.

Michel, A. (1960). Rhétorique et philosophie chez Cicéron. Essai sur les fondements philosophiques de l'art de persuader. Paris: PUF.

Miller, F.D. (2002). Aristotelian Autonomy. En A. Tessitore (Ed.), Aristotle and Modern Politics. The Persistence of Political Philosophy (pp. 375-402). Notre Dame: University of Notre Dame Press.

Nagle, D.B. (2006). The Household as the Foundation of Aristotle's Polis. Cambridge: Cambridge University Press.

Naval Durán, C. (1992). Educación, retórica y poética. Tratado de la educación en Aristóteles. Pamplona: EUNSA.

Nussbaum, M.C. (1978). Aristotle on Teleological Explanation. En M.C. Nussbaum (Ed.), Aristotle's De Motu Animalium: Text with Translation, Commentary, and Interpretative Essays (pp. 59-106). Princeton: Princeton University Press Nussbaum, M.C. (1980). Shame, Separateness, and Political Unity: Aristotle's Criticism of Plato. En A. 0. Rorty (Ed.), Essays on Aristotle's Ethics (pp. 395435). Berkeley: University of California Press.

Nussbaum, M.C. (1986). The Fragility of Goodness: Luck and Ethics in Greek

Tragedy and Philosophy. Cambridge: Cambridge University Press.

Nussbaum, M.C. (1990). Aristotelian Social Democracy. En R. Bruce Douglas

(Ed.), Liberalism and the Good (pp. 203-252). New York: Routledge.

Pettit, Ph. (1999). Republicanismo. Una teoría sobre la libertad y el gobierno. Barcelona: Paidós.

Pocock, J.G.A. (1975). The Machiavellian Moment: Florentine Political Thought and the Atlantic Republican Tradition. Princeton: Princeton University Press.

Ramírez, J.L. (2001). La existencia de la ironía como ironía de la existencia. Una investigación sobre el sentido. Isegoría, 25, 115-145

Ramírez, J.L. (2003a). Tópica de la responsabilidad. Reivindicación de la retórica para la ciudadanía moderna. En J. Conill \& D.A. Crocker (Eds.), Republicanismo y educación cívica ¿Más allá del liberalismo? (pp. 219-242). Granada: Comares.

Ramírez, J.L. (2003b). La Retórica, pórtico de la ciencia. Elementos, 50, 3-7. 
Rawls, J. (1971). A Theory of Justice. Cambridge: Harvard University Press. Rawls, J. (1993). Political Liberalism. New York: Columbia University Press. Rawls, J. (1995). Reply to Habermas. Journal of Philosophy, 92, 132-180. Richardson, H.S. (1997). Practical Reasoning about Final Ends. Cambridge: Cambridge University Press.

Richardson, H.S. (2002). Democratic Authonomy. Public Reasoning about the Ends of Policy. Oxford: Oxford University Press.

Ritter, J. (1969). Metaphysik und Politik. Studien zu Aristoteles und Hegel. Frankfurt am Main: Suhrkamp.

Rorty, R. (1989). Contingency, Irony, and Solidarity. Cambridge: Cambridge University Press.

Rubio-Carracedo, J. (1996). Educación moral, postmodernidad y democracia. Madrid: Trotta.

Salkever, S.S. (1991a). Finding the Mean. Theory and Practice in Aristotelian Political Philosophy. Princeton: Princeton University Press.

Salkever, S.S. (1991b). Aristotle's Social Science. En C. Lord \& D.K. O'Connor (Eds.), Essays on the Foundations of Aristotelian Political Science (pp. 11-48). Berkeley: University of California Press.

Salkever, S.S. (1991c). Women, Soldiers, Citizens: Plato and Aristotle on the Politics of Virility. En C. Lord \& D.K. O'Connor (Eds.), Essays on the Foundations of Aristotelian Political Science (pp. 165-190). Berkeley: University of California Press.

Sandel, M.J. (1998). Liberalism and the Limits of Justice. Cambridge: Cambridge University Press.

Saxonhouse, A.W. (1982). Family, Polity, and Unity: Aristotle on Socrates Community of Wives. Polity, 15, 202-219.

Sherman, N. (1997). Making a Necessity of Virtue. Aristotle and Kant on Virtue. Cambridge: Cambridge University Press.

Taylor, Ch. (1991). The Ethics of Authenticity. Cambridge: Harvard University Press.

Vasoli, C. (1999). L'humanisme rhétorique en Italie au XVe siècle. En M. Fumaroli (Ed.), Histoire de la rhétorique dans l'Europe moderne. 1450-1950 (pp. 45129). Paris: PUF. 
Vattimo, G. (1983). Dialéctica, diferencia y pensamiento débil. En G. Vattimo \& P.A. Rovatti (Eds.), El pensamiento débil (pp. 18-42). Madrid: Cátedra.

Walzer, M. (1983). Spheres of Justice: A Defence of Pluralism and Equality. New York: Basic Books. 